PROCEDIA

Studi Kasus dan Intervensi Psikologi

ISSN:2302-1462; e-ISSN: 2722-7669

Volume 8(2) 55-64, Juni 2020

DOI: $10.22219 /$ procedia.v8i2.13423

\title{
Filial terapi dan token ekonomi untuk meningkatkan kemandirian menulis pada anak dengan problem kemandirian dalam belajar
}

Rahma Fitrah, Universitas Muhammadiyah Malang, Malang, Indonesia

Korespondonesi:

Rahma Fitrah, email: fitrafidewarna@gmail.com

\section{Riwayat artikel Naskah diterima: 21/02/2020}

Revisi diterima: $17 / 04 / 2020$

Naskah disetujui: 14/05/2020

\begin{abstract}
Abstrak
Subjek berusia 7 tahun saat ini kelas 1 SD. Dikeluhkan oleh guru enggan menulis dan mengerjakan tugas sekolah. Subjek menolak dan menangis ketika diperintahkan untuk menyelesaikan tugasnya. Kondisi ini membuatnya tertinggal dalam pencapaian target akademis di sekolah. Subjek minim dalam stimulasi belajar di rumah, seluruh tugas sekolah dikerjakan oleh orang tuanya tanpa memberikan bimbingan untuk mengasah pengetahuan subjek. Selain itu suasana belajar di rumah tidak kondusif dan kerapkali diawali dengan kekerasan fisik. Oleh karena itu kondisi ini diduga membuat subjek menilai bahwa aktivitas belajar adalah aktivitas yang memberikan konsekuensi tidak menyenangkan bagi dirinya. Sejalan dengan hasil psikotes bahwa subjek lemah dalam kemampuan konsentrasi, minat belajar rendah, lemah dalam kemampuan visual motor dan pengamatan. Selain itu dari aspek kepribadian ia mengembangkan perasaan tidak aman, tidak mampu dan ketergantungan yang besar pada orang lain. Berbagai faktor ini lah yang membuat ia kurang mandiri dalam belajar. Keluhan subjek ditangani dengan Filial terapi dikombinasi dengan token ekonomi. Adapun hasilnya adalah, intervensi ini berperan meningkatkan kemandirian belajar pada subjek yang ditunjukkan dengan keterlibatanannya lebih sering dalam aktivitas menulis dan mengerjakan tugas di sekolah maupun di rumah. Hal ini secara tidak langsung berpengaruh pada peningkatan nilai akademis subjek di sekolah.

Kata kunci: filial terapi, token ekonomi, kemandirian belajar
\end{abstract}




\section{Latar Belakang}

Salah satu indikator anak berfungsi secara kompeten di sekolah adalah kemampuannya beradaptasi dan mencapai target akademis sesuai tingkat pendidikannya, salah satunya adalah perihal membaca dan menulis. Keluhan yang seringkali dijumpai pada anak usia sekolah awal adalah, kegagalan dalam melampaui zona perkembangan aktual dan mencapai target perkembangan pada aspek kognitif, emosi, maupun sosial di usianya,berawal dari lingkungan rumah dimana pengasuhan yang dibangun membuat anak terisolasi dan kurangnya stimulasi dalam belajar. Gagal memberi anak-anak pengalaman mengenal huruf sampai usia sekolah dapat sangat membatasi tingkat membaca dan menulis yang akhirnya mereka capai (Williams,2003)

Kondisi demikian dialami oleh oleh subjek yang berusia 7 tahun dan duduk di kelas 1 SD dan menjadi keluhan orang tua serta guru adalah perilaku anak yang tidak mandiri dalam menulis yang ditunjukkan dengan malas menulis, selalu menangis sambil meminta orang tua yang mengerjakan tugas sekolahnya, belum menghafal huruf dan tidak lancar membaca di usia 7 tahun. Adapun pola pengasuhan yang dilakukan oleh ibu dan ayah terhadap subjek dilakukan sengan tidak konsisten. Ayah bersikap acuh tak acuh dengan melimpahkan semua tugas mendampingi, dan mengurus anak kepada ibu. Sedangkan ibu dalam mendampingi anak belajar cenderung untuk menerapkan perilaku-perilaku kekerasan secara fisik dan verbal seperti membentak, memarahi mencubit, menjewer ketika subjek tidak mampu mengerjakan tugasnya. Seringkali ibu memilih tindakan mengambil alih mengerjakan semua tugas-tugas sekolah subjek tanpa mengajari subjek cara mengerjakannya secara mandiri. Karenanya berefek pada rendahnya pencapaian target akademis di usianya saat ini.

Orang tua memiliki tanggungjawab melakukan kontak dengan anak mereka dalam menyelesaikan tugas pekerjaan rumah mereka, bertanggung jawab atas pelaksanaannya. Kerjasama dengan orang tua diperlukan untuk membuat tugas pekerjaan rumah lebih bermanfaat, karena orang tua adalah orang yang menyediakan sumber daya, lokasi belajar, dorongan dan dukungan selama tugas (Bryan \& Sullivan-Burstein, 1997).

Hasil penelitian menunjukkan bahwa anak dan remaja dari orang tua yang menunjukkan kehangatan dalam pola asuh secara konsisten digambarkan sebagai yang paling prososial, kompeten secara akademis dan sosial, serta rendah dalam menunjukkan gejala masalah perilaku. Sebaliknya, anak-anak dengan orang tua yang, permisif, dan tidak terikat menunjukkan hasil yang jauh lebih buruk, penyesuaian diri yang terganggu dari keempat tipe pengasuhan

Terdapat pandangan yang meyakini bahwa model pengasuhan dalam keluarga dapat menjadi sumber munculnya kesulitan-kesulitan perkembangan dan masalah perilaku pada anak. Akan tetapi, dengan proses kognitif yang sadar dan pemahaman terkait cara mendampingi anak dalam kehidupan sehari-hari mendasari tumbuh kembang anak yang optimal (Alivandi \& Ismail, 2010)

Model yang Filial terapi adalah intervensi melalui aktivitas permainan yang menekankan upaya terapeutik dengan menekankan hubungan orang tua dan anak dimana dalam pengasuhannya diterapkan empati dan peningkatan keterampilan relasional sebagai media perubahan (VanFleet \& Topham, 2011). Dalam penerapannya, untuk membut upaya anak merubah perilaku menjadi menyenangkan maka dikolaborasi dengan memberikan konsekuensi berupa hadiah. Ada berbagai cara dalam modifikasi perilaku untuk membentuk perilaku yang diharapkan, seperti pemberian reward, punishment, token ekonomi atau tabungan keping dan juga time out. (Doll \& Barretto, 2013.).

Token ekonomi merupakan bentuk pemberian kupon hadiah apabila anak berperilaku sesuai dengan yang diharapkan Token economi adalah penerapan operant conditioning dengan mengganti hadiah langsung dengan sesuatu yang dapat ditukarkan kemudian. Disebut operant karena memberikan perlakuan terhadap lingkungan yaitu berupa hadiah kepada tingkah laku. Dengan adanya hadiah perilaku akan terus berulang atau muncul (Doll \& Barretto, 2013.). 
Penelitian membuktikan bahwa konsekuensi dari keterlibatan dalam pengasuhan dengan cara tertentu yang memberikan hasil mengatasi permasalahan tumbuh kembang anak memiliki efek pada diri orang tua dimana mereka dapat menumbuhkan perasaan berharga, serta mengurangi perasaan bersalah dan tidak berdaya. (Stover \&Guerney, 1967).

Sehingga, penanganan kasus ketidakmandirian belajar yang dialami oleh subjek akan ditangani dengan penerapan Filial terapi yang dikolaborasi dengan token ekonomi, untuk mengedukasi dan melatih keterampilan orang tua dalam mendampingi anak belajar dan beraktivitas di kehidupan sehari-hari dengan cara yang tepat sehingga dapat menumbuhkan kemandirian belajar dan menjadikan aktivitas belajar menjadi menyenangkan karena konsekuensi menyenangkan yang ia dapatkan berupa perhatian maupun hadiah yang nantinya membuat anak dapat beradaptasi dengan baik pada tugas akademis.

\section{Metode Asesmen}

Asesmen untuk penegakan diagnosa yang tepat dilakukan melalui serangkaian metode antara lain wawancara, observasi, kuisioner dan tes psikologi. Wawancara dilakukan terhadap untuk memperoleh informasi lebih mendalam tentang riwayat permasalahan yang subjek alami. Wawancara, dilakukan dengan menggunakan wawancara semi terstruktur dengan pertanyaan terbuka yang disusun berdasarkan aspek-aspek/ ciri-ciri diagnosa gangguan yang ingin digali dari kehidupan subjek. Adapun dalam pelaksanaannya pertanyaan akan dikembangkan berdasarkan jawaban yang diberikan oleh klien maupun significant other wawancara jenis ini digunakan untuk mengetahui secara mendalam mengenai riwayat permasalahan, serta pikiran dan perasaan klien terkait berbagai kejadian dalam hidupnya.

Observasi dilakukan dengan bantuan checklist yang sistematis untuk mengidentifikasi beberapa aspek seperti penampilan, aktivitas psikomotor, komunikasi, sikap terhadap lingkungan social dan tanggungjawab yang ia kerjakan sehari-hari.

Selain Observasi dan wawancara, asesmen juga dilengkapi dengan tes psikologis yaitu tes kecerdasan dan kepribadian. Tes psikologi digunakan sebagai alat konfirmasi atas data yang diperoleh dari wawancara dan observasi, membuat dinamika kepribadian dan mengetahui kebutuhan intervensi subjek.

Tes inteligensi menggunakan Wescler adult intelligence scale (WISC) digunakan untuk mengetahui kapasitas intelektual serta ada atau tidaknya kemunduran mental pada subjek. Selain itu, melalui tes WISC pada subtes verbal akan membantu untuk mengetahui gaya verbalisasi klien dan pada subtes performance untuk mengetahui sejauh mana ia mampu mampu memerepsi informasi yang ia peroleh secara visual dan seberapa tepat ia memunculkan tindakan yang sesuai. Dengan mengetahui kedua hal ini, akan membantu terapis untuk menyusun cara penyajian intervensi agar target intervensi dapat dicapai.

Tes kepribadian yang digunakan yaitu CAT dan tes GRAFIS yang terdiri dari BAUM, DAP dan HTP. Adapun CAT digunakan untuk mengetahui kebutuhan dan juga tekanan yang subjek alami dari lingkungannya, konflik perasaan dan kebutuhan, serta emosi yang dimunculkan dalam berbagai keadaan serta mekanisme pertahanan diri yang mendominasi.

Tes grafis dipergunakan untuk mengetahui kepribadian subjek secara lebih mendalam, melalui DAP akan membantu mengetahui bagaimana subjek mengidentifikasi dirinya, kontaknya dengan realita dan lingkungan sosialnya serta symptom-symtom klinis yang yang diproyeksikan oleh subjek. BAUM akan membantu mengetahui bagaimana gambaran ego dan dorongan ketidaksadaran (unconsciousness) yang mendominasi. HTP akan membantu memberikan gambaran terkait tentang keberadaan diri subjek di lingkungan keluarga, penilaiannya dan emosi yang dirasakan terhadap figur-figur di keluarga serta interaksi yang dilakukan dalam keluarga 


\section{Presentasi Kasus}

Subjek (Laki-laki/7 tahun) saat ini bersekolah Kelas 1 SD. Keluhan yang disampaikan oleh orang tua dan gurunya adalah subjek tidak mau menulis, mudah lupa, terkadang tidur pada saat kegiatan belajar mengajar berlangsung dan sering mengganggu atau mengajak bermain teman-temannya di kelas. Akibatnya subjek menjadi kurang memenuhi standar belajar yang ditargetkan oleh gurunya yang dibuktikan dengan, tugas-tugasnya yang seingkali tidak ia selesaikan, nilai yang rendah dan tidak menghafal beberapa huruf sehingga terkendala dalam memahami pelajarannya.

Menurut keterangan gurunya subjek seringkali lambat atau memerlukan waktu yang lama serta sulit mempertahankan konsentrasi ketika menulis, ia sering menangis dan meminta untuk dibantu oleh ibunya untuk mengerjakan tugas-tugasnya ketika di sekolah, hal ini membuat subjek menjadi jarang menggunakan waktu istirahatnya untuk bermain karena harus menyelesaikan tugasnya yang belum ia kerjakan di jam pelajaran, disisi lain ia menjadi sangat bergantung pada ibunya dan hanya mau menyelesaikan tugasnya jika dibantu oleh ibu. Berdasarkan hasil dari tes kepribadian diperoleh gambaran bahwa subjek cenderung mengembangkan perasaan tidak aman dan tendensi peerasaan tidak mampu, kurang bersemangat dan ketergantungan yang besar pada pada figure ibu

Sejalan dengan itu kesulitan dalam adaptasi pada pelajaran dijelaskan pula berdasarkan, hasil asesmen menggunakan WISC dimana subjek memiliki IQ 96 yang berada pada katagori rata-rata. Dengan kapasitas IQ yang demikian, pada dasarnya subjek dinilai mampu dalam beradaptasi pada tuntutan akademis seusianya. Adapun hal yang memperburuk peformas subjek dalam beradaptasi dengan tuntutan akademis dapat dikarenakan beberapa aspek kecerdasan yang berada dalam katagori rendah yaitu pada subtes symbol angka, melengkapi gambar, persamaan dan rentang angka ia rendah dalam ingatan jangka pendek sehingga hal ini mempengaruhi konsentrasi subjek yang buruk dalam belajar, kurangnya minat membaca dan sulit beradptasi pada hal-hal yang detail, relative mudah stress dan gampang menyerah ketika dihadapkan pada situasi-situasi yang sulit.

Dalam keseharian subjek dididik dengan pola pengasuhan yang tidak konsisten antara ayah dan ibunya. Ayahnya selalu memanjakan dan menuruti semua keinginan subjek. Ketika subjek enggan untuk belajar dan mengerjakan tugas sekolah, ayahnya memberi kebebasan dan tidak menasehati bahwa tugasnya perlu untuk diselesaikan terlebih dahulu. Disisi lain ayah menuntut ibu untuk sepenuhnya mendampingi subjek belajar tanpa mau terlibat bekerjasama dengan ibu. Adapun cara yang dipilih ibu dalam mendampingi subjek belajar adalah dengan mengerjakan semua PR subjek tanpa menstimulasi subjek untuk mengahafal huruf dan mandiri dalam menulis. Ibu juga mengakui kerapkali dalam mendampingi belajar ia membentak, mencubit dan memarahi subjek ketika subjek enggan menulis dan tidak mengerti cara mengerjakan tugasnya. Kondisi tersebut sejalan dengan hasil tes kepribadian yang terungkap pada CAT dimana subjek merepres perasaan kecemasan akan bahaya fisik dan, tekanan berupa hukuman fisik, ancaman dan kemarahan orang disekitarnya

Subjek yang kerapkali berkata "tidak bisa", "tidak tahu" setiap kali diminta untuk melakukan sesuatu. Hal tersebut sejalan dengan hasil tes grafis subjek dimana ia mengembangkan Perasaan tidak pasti, perasaan tertekan berhubungan dengan lingkungan, kurang semangat, mengembangkan perasaan tidak mampu. Sehingga dapat diduga bahwa pola pengasuhan yang terdiri dari cara pendampingan berlajar, kurangnya stimulasi dan situasi rumah yang tidak kondusif menjadi faktor yang membentuk subjek menjadi kurang mandiri dalam belajar dan menyelesaikan penugasan sekolah.

Akan tetapi, disisi lain subjek memang memiliki minat dan adaptasi yang cukup baik pada lingkungan sosial, konsep nonverbal yang cukup baik sehingga potensi ini dapat dimanfaatkan 
untuk mencarikan media belajar yang tepat guna membantu subjek mencapai target akademis seusianya.

Kondisi yang terjadi pada subjek tersebut menggambarkan problem kemandirian belajar yang secara tidak langsung mempengaruhi kondisi emosional yang kurang mandiri dan sangat bergantung pada bantuan orang tua, problem solving yang buruk dalam mengerjakan tugas-tugas akademis, keengganan menulis dan pencapaian akademis yang buruk. Kemandirian belajar adalah berkembangnya kesadaran diri dan kontrol proses mental dalam aktivitas belajar (David et al. 2005). Adapun kemandirian belajar terdiri dari aspek 1) Kemandirian Kognitif yaitu Kesadaran diri terhadap proses mental/dapat melakukan refleksi pada apa yang dipelajari ditunjukkan dengan memahami maksud dari pelajaran/penugasan; 2) Kemandirian Prososial yaitu Terlibat secara kooperatif dalam beraktivitas belajar dengan teman sebaya; 3) Kemandirian emosional yaitu mengatasi tugas-tugas yang dipelajari dengan penuh percaya diri dan fokus (tidak terdistraksi); 4) kemandirian motivasi yaitu ersemangat untuk melakukan aktivitas (belajar) dan mengembangkan ide

Adapun kondisi kemandirian belajar yang dialami oleh subjek disetiap aspeknya masih kurang dalam keseharian. Dari segi kemandirian kognitif ditunjukkan dengan sering menyontek jawaban teman atau tidak mengerjakan sama sekali jika tidak dibantu oleh ibu, sering mengeluh tidak bisa, hanya mau menjawab pertanyaan secara lisan namun enggan menuliskannya. Dari segi kemandirian emosional subjek menunjukkan ketidakpercayaan diri mengerjakan tugasnya sendiri, selalu merasa tidak bisa. Dari segi kemandirian prososial terkadang subjek mau jika diajak belajar bersama dan dilain waktu terkadang menunjukkan keengganan belajar dengan teman dan hanya bermain di kelas. Dari segi kemandirian motivasi subjek juga dinilai kurang karena selalu menangis ketika diperintah menyelesaikan tugas dan belajar serta menangis ketika tidak dibantu mengerjakan oleh ibunya. Berdasarkan gambaran tersebut, diketahui bahwa sebagian besar aspek kemandirian belajar pada subjek masih belum terpenuhi, sehingga subjek dikatagorikan mengalami problem kemandirian belajar.

Ketidakmandirian belajar dapar dibentuk melalui proses belajar dan pengamatan pada situasi yang dialami oleh subjke sehari-hari. Menurut Bandura (1997) individu seharusnya dipahami sebagai suatu fungsi psikologis sebagai hasil hubungan saling pengaruh yang terus-menerus antara perilaku, kognisi dan lingkungan. Inti dari teori belajar sosial Bandura, individu membentuk citra kognitif tentang bagaimana perilaku tertentu dibentuk dengan cara mengamati model dan mempelajari penguatan dari perilaku yang dilakukan.

Skema hubungan segitiga antara lingkungan, faktor personal dan tingkah laku ketidakmandirian belajar pada subjek dimulai dari kondisi lingkungan yaitu tidak konsistennya orang tua subjek dalam mengasuh dan mendampingi belajar di rumah, ayah cenderung memberi kebebasan untuk tidak belajar, membela jika subjek menangis dan tidak ingin menulis dengan menyuruh ibu subjek yang mengerjakan semua tugas sekolah subjek, serta mendapatkan perlakuan seperti dibentak, dicubut dan dijewer sehingga pengalaman belajar menjadi tidak menyenangkan bagi subjek. Dari segi kognitif, subjek, meyakini bahwa belajar merupakan aktivitas yang tidak menyenangkan, ia tidak mampu mengerjakan tugasnya sendiri, dan semua tugas sekolah pasti akan secara otomatis diambil alih oleh ibu jika ia menangis dan meminta pembelaan kepada ayah. Sedangkan faktor perilaku yang akhirnya dimunculkan oleh subjek adalah keengganan untuk menulis baik di rumah dan sekolah, menangis setiap kali diperintahkan untuk belajar dan mengerjakan tugas, selalu meminta pembelaan dari ayah agar ayah menyuruh ibu yang mengerjakan tugas sekolahnya.

Dalam teori belajar sosial, berpendapat bahwa pengalaman kehidupan nyata anak-anak dan paparan langsung atau tidak langsung dari orang tua berupa perilaku pengaturan perilaku dalam pengasuhan orang tua dapat menjadi situasi yang membentuk perilaku anak. Model pengasuhan yang cenderung menekankan konflik orang tua, paksaan cenderung membentuk perilaku agresif. 
Dimensi positif pengasuhan sebagai cara mempromosikan perilaku dan pengaruh positif anak, meningkatkan sifat menyenangkan interaksi orang tua dan anak-anak satu sama lain. Prinsip mendasarnya adalah bahwa interaksi timbal balik dari waktu ke waktu sangat penting; jika seorang anak menerima hadiah langsung atas perilakunya, seperti mendapatkan perhatian atau persetujuan orang tua, maka ia cenderung melakukan perilakunya lagi, sedangkan jika ia diabaikan (atau dihukum) maka ia kurang kemungkinan melakukannya lagi. Pendukung lain telah memperluas fokus ini untuk mempertimbangkan proses kognitif atau 'sadar' yang mendasari perilaku orang tua (Bugenthal et al., 1998)

Sebab akibat ketidakmandirian belajar yang dialami oleh subjek dapat dijelaskan dari Konsep teori pola asuh yang dijelaskan oleh Bernard dan Louise Guerney dimana kondisi kurangnya pemahaman orang tua tentang perkembangan dan keterampilan manajemen anak menjadi penyebab masalah dalam diri anak mereka (Guerney, 2003). Akan tetapi jika jika orang tua menerima pendidikan pengasuhan yang tepat dan dan diterapkan dalam proses pengasuhan, maka sangat mungkin orang tua bisa menjadi sumber perubahan yang berharga dalam diri anak mereka.

Untuk membenahi kekeliruan orang tua dalam mengasuh dan mendampingi tumbuh kembang anak, dapat diterapkan sebuah intervensi berbasis terapi bermain yang menekankan hubungan antara orang tua-anak.FT didasarkan pada pemikiran bahwa hubungan orang tua-anak adalah aspek yang paling signifikan dan kuratif dalam kehidupan anak (Landreth \& Bratton, 2006).

FT adalah program terapi bermain terstruktur yang digunakan untuk orang tua dan anak-anak usia 2 dan 10 (Guerney, 2003). Tujuan keseluruhan dalam FT adalah untuk memperkuat hubungan orang tua-anak; ini dicapai dengan mengajar dan membekali orang tua dengan keterampilan terapi permainan untuk menjadi agen terapi dalam kehidupan anak mereka (Landreth \& Bratton, 2006). Dalam FT orang tua belajar keterampilan menyampaikan penerimaan, empati, dan dukungan kepada anak mereka, dan untuk fokus pada peningkatan hubungan anak dan orang tua-anak daripada masalah anak perilaku (Bavin-Hoffman, Jennings, \& Landreth, 1996). Karena alasan inilah FT terbukti lebih sukses dan efektif daripada metode terapi bermain lain karena orang tua yang terlibat dalam proses terapi (Landreth \& Bratton, 2006)

\section{Diagnosis dan Prognosis}

Hasil diagnosis subjek mengarah Problem kemandirian belajar yang spesifik pada keluhan keengganan menulis dan mengerjakan tugas sekolah secara mandiri sehingga mempengaruhi buruknya nilai dan pencapaian target akademis di sekolah.

Prognosis positif karena adanya motivasi pada diri subjek untuk terlibat pada sesi intervensi. Selain itu, orang tua yang kooperatif dan terbuka untuk menerima edukasi yang disampaikan oleh terapis dan hadir untuk mempelajari banyak hal baru pada setiap sesi terapi dan mencoba menerapkannya di rumah. Faktor-faktor lain adalah perekonomian keluarga yang masuk dalam katagori menengah dan mau berkontribusi menyiapkan reward bagi perilaku target subjek yang berhasil tercapai,selain itu, guru si sekolah yang turut mengingatkan dan memotivasi subjek untuk menjadi lebih rajin dalam menulis dan mengerjakan tugas sekolah.

\section{Intervensi}

Permasalahan kurangnya kemandirian dalam belajar dan menyelesaikan penugasan sekolah yang dialami oleh subjek disebabkan oleh pola pengasuhan yang tidak konsisten orang tua, cara pendampingan berlajar yang keliru, kurangnya stimulasi dan situasi rumah yang tidak kondusif. Maka, filial therapy yang dikolaborasi dengan token ekonomi dipilih sebagai intervensi untuk mengatasi permasalahan tersebut 
Filial Therapy adalah intervensi yang dilakukan dengan tujuan untuk peningkatan hubungan antara anak dengan orang tua. Dimana orang tua diajarkan keterampilan yang diperlukan untuk melakukan sesi bermain yang berpusat pada anak dengan anak mereka guna mengatasi berbagai perilaku bermasalah pada anak, saah satunya ketidakmandirian belajar pada anak.

Token ekonomi adalah prosedur pemberian satu kepingan (satu tanda atau isyarat) sesegera mungkin setelah perilaku yang diharapkan muncul, nantinya kepingan ini dapat ditukar dengan benda atau aktivitas reward yang diinginkan subjek. Bentuk dari token ekonomi dapat berupa angka, cek, kartu, mainan yang berbentuk uang, stampel dsb (Doll C\& Barretto, 2013.)

Token ekonomi adalah sebuah sistem penguatan yang diberikan untuk anak-anak dengan hadiah nyata bagi perilaku tertentu. Penghargaan ini, atau "token," akan terkumpul sehingga anak dapat menukar token mereka dengan hadiah atau aktivitas yang sebenarnya.

FT melibatkan pasangan orang tua-anak dan mengedukasi dan mendorong kemampuan orang tua untuk menjadi agen terapi untuk anak-anak mereka sendiri melalui permainan. FT mencakup empat keterampilan dasar, yaitu, (a) Keterampilan imajiner yang berpusat pada anak; (b) Keterampilan penataan; (c) Keterampilan empatik; dan (d) Keterampilan menetapkan batas (Guerney, 2003).

Konteks permainan empati dan tidak menghakimi yang disediakan oleh FT menciptakan lingkungan di mana anak-anak dapat mengekspresikan diri secara terbuka. Sementara anak-anak mengalami penerimaan orang tua mereka yang tidak menghakimi di ruang bermain dan mulai memainkan masalah yang mengganggu di hadapan orang tua mereka, mereka mulai menerima bahwa orang tua mereka benar-benar dapat melakukan perilaku yang sama di luar ruang bermain (Landreth, 2002b).

Pembiasaan-pembiasaan perilaku yang diterapkan pada filial terapi pada akhirnya dinilai akan mengedukasi orang tua tentang cara pendampingan anak secara tepat dalam kehidupan sehari-hari, dimana hal tersebut nantinya akan membantu mengatasi ketidakmandirian anak dalam aktivitas belajar dengan menumbuhkan kemandirian belajar pada anak.

Adapun pemilihan permainan disesuaikan dengan perilaku yang menjadi target intervensi. Dalam hal ini, perilaku yang menjadi target intervensi adalah kemandirian dalam belajar yang spesifik pada (mengarahkan fokus, memaksimalkan kinerja memori jangka pendek, serta bertanggungjawab pada tugas yang harus diselesaikan secara mandiri). Dalam hal ini permainan yang dipilihkan adalah flashcard, bermain plastisin dan pasir (mencetak dan membentuk huruf dengan plastisin dan pasir), menebalkan huruf putus-putus dengan pensil warna, bermain peran guru-murid, bermain dongeng bertema aktivitas belajar di kelas. Prosedur terapi dilakukan dengan dilakukan dengan urutan sebagai berikut.

Sesi 1: Membangun Rapport. Terapis memperkenalkan diri serta pelayanan yang akan diberikan sesuai dengan kebutuhan dan keluhan psikologis. Membangun kepercayaan klien untuk terlibat secara konsisten. Pada tahap ini subjek yang didampingi oleh orang tuanya menunjukkan sikap yang terbuka dan percaya diri untuk berkenalan dengan terapis. Subjek menunjukkan ekspresi senang ketika diperkenalkan dengan beberapa permainan, antusias ketikadiajak bermain dan menyetujui ajakan terapis untuk bertemu lagi 2 kali seminggu. Adapun orang tua yang mendampingi subjek pada sesi ini mampu memahami gambaran pelayanan psikologis yang akan diberikan dan menyepakati durasi terapi psikologis dan jadwal pertemuan yang rencananya diagendakan 2 kali seminggu.

Sesi 2: Identifikasi masalah. Dalam proses ini klien diajak untuk mengidentifikasi masalah spesifik yang terjadi pada anak yang nantinya akan memperoleh penanganan psikologis. Adapun perasalahan terkait kemandirian belajar anak yang rendah sehingga berpengaruh pada keengganan untuk menulis dan menyelesaikan tugas sekolah. Selanjutnya merumuskan mengenali hal-hal yang perlu dibenahi dalam diri anak untuk mengatasi permasalahan tersebut. Aktivitas ini mengarah kepada penetapan tujuan atau target perubahan yang perlu dicapai. 
Pada tahap ini orang tua yang menjadi bagian dari proses terapi terbuka dalam menceritakan permasalah belajar yang dialami oleh anaknya yaitu keengganan dalam menulis yang sudah dialami selama duduk di kelas 1 selama 6 bulan belakangan ini. Orang tua kooperatif memberikan informasi terkait keseharian pendampingan belajar subjek di rumah dan peforma akademik subjek di sekolah.

Pada sesi ini terapis juga melakukan beberapa pemerikasaan kepada subjek, terkait kemampuan menulis, menghafal huruf dan tes psikologis untuk memperdalam data tentang permasalahan subjek. Adapun pada pelaksanaannya subjek bersedia untuk mengikuti perintah terapis dan melakukan beberapa aktivitas yang ditugaskan oleh terapis seperti menyebutkan huruf, menuliskan huruf dan bercerita tentang alasan keengganan menulis baik di rumah maupun di sekolah. Melalui aktivitas ini diperoleh gambaran sumber permasalahan subjek dalam belajar disebabkan oleh sikap orang tua yang melakukan kekerasan fisik maupun verbal dalam mendampingi subjek belajar. Adapun terkait kemampuan subjek lainnya terdeteksi melalui serangkaian tes psikologis.

Sesi 3: Menyampaikan tujuan Filial Terapi kepada orang tua. Pada tahap ini Terapis menyampaikan terkait tujuan filial terapi untuk melatih orang tua menjadi agent terapi untuk perilaku bermasalah pada anak dengan mengasah penerapkan keempat aspek yaitu keterampilan imajiner yang berpusat pada anak, keterampilan penataan, keterampilan empatik, keterampilan menetapkan batas. Dimana keempat aspek tersebut nantinya dapat membekali orang tua dalam melakukan pendampingan pada anak di kehidupan sehari-hari baik pada aktivitas bermain maupun belajar.

Pada pelaksanaan sesi ini, terapis mengawali dengan memahamkan orang tua terkait hasil pemeriksaan psikologis dan data wawancara yang telah diperoleh pada sesi sebelumnya. Terapis menjelaskan berbagai faktor yang menyebabkan subjek mengalami problem dalam belajar, terkait sikap orang tua yang keliru dalam mendampingi subjek belajar sehingga subjek terkondisi tidak mandiri dan mempengaruhi buruknya peforma di sekolah. Adapun berdasarkan penjelasan yang disampaikan oleh terapis, orang tua memahami kekeliruannya dan termotivasi untuk memperbaiki sikapnya dalam mendampingi anak belajar. Hal ini menunjukkan terbangunnya komitmen yang semakin kuat pada diri orang tua yang nantinya akan banyak dilibatkan sebagai agent terapi bagi subjek.

Setelah orang tua menunjukkan komitmen untuk turut menjadi agen terapi, aktivitas dilanjutkan dengan menjelaskan tujuan filial therapy, aspek-aspeknya beserta cara penerapannyakepada anak dalam perilaku konkrit.

Adapun pada tahap ini, melalui penjelasan yang berulang-ulang dan dengan contoh yang diberikan oleh terapis, orang tua memahami apa saja tugas dan keterampilan yang harus ia latih seperti (a) Keterampilan imajiner yang berpusat pada anak; (b) Keterampilan penataan; (c) Keterampilan empatik; dan (d) Keterampilan menetapkan batas dimana keempat keterampilan tersebut akan diterapkan dalam perilaku konkrit yang nantinya terus-menerus diterapkan dalam mendampingu subjek berlajar sehari-hari.

Sesi 4: Mensimulasikan sesi bermain oleh terapis sementara ibu ditugaskan untuk memperhatikan. Pada tahap ini Terapis melakukan sesi permainan bersama anak sambil menerapkan secara kolaboratif keempat aspek filial terapi. Sedangkan orang tua ditugaskan untuk memperhatikan cara penerapannya dalam permainan yang dilakukan. Adapun permainan yang dimainkan adalah Flash card, Membentuk huruf dengan plastisin dan pasir, menebalkan pola huruf, bermain peran, dongeng. (Nama permainan dan langkah penerapannya dilampirkan).

Pada pelaksanaannya orang tua menunjukkan sikap yang fokus memperhatikan terapis menerapkan aspek filiat terapi dalam bentuk-bentuk perilaku konkrit seperti selama bermain terapis mendukung ide-ide anak ketika ia bermain, bernegosiasi kepada anak tentag lamanya 
aktivitas bermain yang dilakukan, memberikan perhatian, dukungan emosional dan mendorong kemandirian anak dalam mengatasi kesulitan ketika bermain.

Sesekali, dalam sesi simulasi dan roleplay ini, terapis memberi penjelasan pada setiap perilaku yang ditekankan untuk diingat cara penerapannya oleh orang tua. Adapun hasil akhir dari sesi ini, Subjek mengaku merasa senang dan semangat belajar huruf sambil bermain. Selain itu, orang tua memahami terkait cara menerapkan keterampilan filial therapy dalam bentuk perilaku konkrit. Orang tua juga memahami bahwa perilaku-perilaku tersebut dapat diterapkan pula pada aktivitas mendampingi anak belajar nantinya.

Sesi 5: Melatih orang tua dalam menerapkan empat keterampilan FT di bawah pengawasan langsung terapis. Pada tahap ini orang tua ditugaskan untuk menerapkan ulang sesi bermain bersama dengan anak. Dalam penerapannya, terapis memotivasi orang tua untuk memunculkan aspek-aspek FT terapi seperti: keterampilan imajiner yang berpusat pada anak, keterampilan penataan, keterampilan empatik, keterampilan menetapkan batas. Kemudian terapis mencatat terkait keterampilan apa saja yang telah berhasil dan belum berhasil diterapkan dengan baik.

Pada tahap ini awalnya orang tua mengaku merasa canggung dan kurangv percaya diri dalam melakukan permainan bersama subjek sambil menerapkan keterampilan filial therapy. Namun setelah, mendapatkan dukungan dan pujian dari terapis serta melihat antusiasme anaknya dalam bermain menghafalkan huruf dan menuliskan huruf, orang tua termotivasi untuk mencobakan secara berulang hingga mampu menerapkan setiap keterampilan filial therapy dalam bentuk perilaku konkrit sebagaimana yang dicontohkan oleh terapis pada sesi sebelumnya.

Adapun pada akhir sesi ini, orang tua merasa senang karena mampu membantu anaknya menghafalkan huruf melalui aktivitas bermain yang menyenangkan sambil menerapkan keterampilan filial therapy. Orang tua merasa menerapkan aspek filial therapy cukup mudah untuk dilakukan dan berkomitmen untuk mulai menerapkannya dalam mendampingi subjek berlajarsehari-hari. Disisi lain, dari sesi ini diketahui bahwa Subjek mengaku senang apabila bermain bersama ibunya dengan sikap diberikan pujian, dukungan dan diberi kesempatan mencoba perilaku yang ia inginkan.

Sesi 6: Evaluasi penerapan keempat aspek FT pada sesi bermain. Pada tahap ini terapis mengevaluasi penerapan aspek-aspek Filial terapi yang telah mampu diterapkan oleh orang tua dan anak selama bermain bersama. Keberhasilan dalam penerapan akan diberikan apresiasi dan dimotivasi untuk terus diterapkan. Sedangkan untuk aspek yang belum diterapkan secara maksimal, akan dilatih bersama dengan terapis hingga orang tua dan anak mengerti cara menerapkannya.

Hasil pada sesi ini adalah, terapis memberikan feedback, bahwa orang tua sudah cukup mampu menerapkan keempat aspek filial therapy. Terapis memberikan saran kepada orang tua untuk terus berlatih dan menerapkannya diberbagai aktivitas saat mendampingi subjek sehari-hari serta lebih meningkatkan kepercayaan diri dan ketulusan dalam menerapkannya. Orang tua merasa senang dan menerima saran dari terapis untuk meningkatkan kepercayaan diri dan ketulusan agar ia menjadi lebih luwes dalam menerapkan aspek-aspek filial terapi ke dalam perilaku konkrit. Orang tua termotivasi untuk terus menerapkan aspek filial therapy dalam berbagai aktivitas mendampingi subjek sehari-hari.

Sesi 7: Memberikan penugasan kepada orang tua dan anak untuk melaksanakan sesi bermain di rumah. Untuk membuat orang tua dan anak terbiasa berlatih dengan penerapan aspek-aspek filial terapi, maka diberi penugaan untuk melanjutkan permainan di rumah. Selanjutnya menceritakan kepada terapis tentang bentuk-bentuk penerapan setiap aspek serta keberhasilan penerapannya.

Hasil dari penerapan bermain sambil belajar huruf di rumah bersama antara orang tua dan subjek, orang tua melaporkan bahwa ia mampu mendampingi anak dengan menerapkan aspek 
filial terapi dalam bentuk perilaku konkrit. Ia juga mengakui bahwa dengan keterampilan yang ia terapkan tersebut ia menjadi jarang memarahi dan memukul, menjewer serta mencubit subjek. Adapun subjek menjadi lebih bersemangat ketika diajak belajar menghafalkan huruf sambil bermain, dan ia sesekali mau ketika disuruh menulis karena orang tuanya kerapkali memberikan semangat dan memuji dirinya dan mampu menambah jumlah huruf yang ia hafalkan, ia juga mengakui bahwa ibunya sudah jarang memarahi dan mencubitnya ketika belajar.

Sesi 8: Memperkenalkan konsep token ekonomi untuk membentuk perilaku kemandirian belajar. Pada sesi ini anak dan orang tua diberikan penjelasan tentang aturan dalam penerapan token ekonomi untuk membentuk perilaku, yaitu pemberian konsekuensi menyenangkan/ reward yang diberikan setelah beberapa perilaku yang disepakati/ditargetkan muncul atau diterapkan oleh anak. Setiap perilaku yang muncul akan diberi 1 stampel. Akumulasi dari stampel yang didapatkan, jika mencapai jumlah target akan ditukarkan dengan reward yang disepakati misalnya mainan. Dalam hal ini Setiap kemunculan perilaku yang menggambarkan indikator kemandirian belajar yang spesifik mengarah pada perilaku menulis akan ditandai dengan stempel senyum. Dimana stempel yang dikumpulkan tersebut dapat ditukarkan dengan hadiah ketika mencapai jumlah minimal yang disepakati.

Adapun hasil dari sesi ini, orang tua dan subjek memahami prosedur dan aturan yang berlaku untuk mendapatkan stampel yang dapat ditukarkan dengan reward/hadiah. Subjek menunjukkan sikap antusias ketika mengetahui bahwa setiap sikapnya yang menunjukkan semangat belajar dan menulis akan mendapatkan stampel yang akan ditukarkan dengan hadiah yang ia harapkan.

Sesi 9: Desain implementasi. Menyepakati dengan anak bentuk-bentuk perilaku kemandirian yang harus diterapkan dalam belajar baik di rumah maupun di sekolah. Anak diberi penjelasan bahwa setiap perilaku yang berhasil ia lakukan akan ditandai dengan stempel senyum yang nantinya akan diakumulasi untuk ditukarkan dengan hadiah.

Laporan penerapan perilaku dibuat dalam bentuk jurnal harian yang diisi oleh guru di sekolah dan dan orang tua di rumah untuk melihat konsistensi penerapan kemandirian belajar di rumah dan di sekolah.

Selain itu, pada orang tua diberi penugasan dalam bentuk jurnal harian yang berisi catatan penerapan aspek-aspek FT dalam mendampingi anak belajar di rumah yang dikolaborasikan dengan token ekonomi.

Hasil dari penerapan sesi ini, subjek mampu memahami bahwa setiap perilakunya akan dipantau oleh orang tua dan guru di sekolah. Apabila ia mampu untuk menunjukkan kemandirian belajar mulai dari menyiapkan alat tulis, menulis sendiri, tidak bermain dan mengganggu teman selama jam pelajaran, dan membereskan alat tulisnya ia akan mendapatkan stampeldari setiap kemunculan perilaku tersebut dan dapat menukar stampel tersebut dengan hadiah yang ia minta yaitu mainan.

Selain itu, pada desain implementasi yang harus dilakukan orang tua, orang tua subjek memahami bahwa dalam keseharian ia perlu melaporkan dalam bentuk checklist penerapan aspek filial therapy dalam bentuk perilaku konkrit seperti, memberi kesempatan anak untuk mengerjakan sendiri, menyemangati, memuji, memberikan sentuhan fisik seperti memeluk dan mengelus kepala yang ia terapkan dalam mendampingi subjek belajar. Orang tua menilai ia cukup mampu untuk menerapkan hal tersebut dalam mendampingi subjek belajar.

Sesi 10: Evaluasi. Memeriksa dan mendisuksikan penerapan keterampilan Filial Terapi dan Token Ekonomi untuk mendorong kemandirian belajar anak. Mengidentifikasi hal-hal yang sudah tercapai dan belum tercapai dari jurnal harian, pemberian feedback serta motivasi untuk melanjutkan implementasi program.

Hasil penerapan pada sesi ini, subjek menunjukkan peningkatan keterlibatan pada perilaku-perilaku yang menggambarkan kemandirian belajar terutama dalam aktivitas 
menyiapkan alat tulis dam membereskannya, kemauan untuk menuruti ajakan belajar dan menulis/ mengerjakan sendiri tugas sekolah yang diberikan baik di rumah maupun di sekolah, mengikuti kegiatan belajar di kelas tanpa bermain dan mengganggu teman walaupun dalam penerapannya, subjek masih kerapkali mendapatkan bantuan berupa contoh dari guru maupun orang tua dikarenakan ia belum begitu lanjar dalam membaca dan belum menghafal seluruh huruf.

Selain itu, pada tahap evaluasi terhadap penugasan pada orang tua, orang tua subjek juga menunjukkan peningkatan keterlibatan pada perilaku-perilaku yang menggambarkan penerapan aspek filial terapi seperti mengkolaborasikan sikap seperti memberi kesempatan anak untuk mengerjakan sendiri, menyemangati, memuji, memberikan sentuhan fisik seperti memeluk dan mengelus kepala yang ia terapkan dalam mendampingi subjek belajar. Orang tua melaporkan bahwa dengan menerapkan sikap-sikap tersebut, mereka menjadi dapat mengurangi kebiasaan membentak, mencubit dan menjewer anaknya. Mereka juga mendapati anak menjadi lebih menunjukkan minat ketika diajak belajar dan mengerjakan PR di rumah.

Sesi 11: Terminasi. Mengakhiri rangkaian intervensi dan memotivasi subjek serta orang tua untuk mempertahankan perubahan positif yang telah mereka capai pasca intervensi.

Hasil dari tahap ini, subjek menyetujui ketika diajak untuk melanjutkan perubahan positif yang telah ia lakukan yaitu kemandirian dalam belajar, hal tersebut karena subjek menyukai aktivitas belajar yang menyenangkan dan hadiah yang ia dapatkan apabila ia rajin belajar (mau mandiri dalam menulis tugas sekolahnya sendiri). Begitupun pada orang tua, mereka juga berkomitmen untuk terus melanjutkan pendampingan dengan sikap yang positif karena melihat keuntungan yang didapatkan berupa peningkatan minat dan kemandirian anak dalam belajar.

Sesi 12: Follow up. Dilakukan minimal 2 minggu setelah penanganan dengan tujuan untuk melihat sejauh mana aspek-aspek yang dipelajari pada filial tetap dilanjutkan penerapannya oleh orang tua dalam mendampingi subjek belajar dan pengaruhnya terhadap penerapan kemandirian belajar subjek.

Hasil dari sesi follow up ini adalah, diperoleh informasi bahwa subjek mampu menerapkan kemandirian belajar dalam keseharian baik di rumah maupun di sekolah. Hal tersebut ditunjukkan dengan ia lebih banyak terlibat untuk belajar di kelas, jarang mengganggu temannya dikelas. Adapun kemandirian belajar ini turut berpengaruh pada peningkatan nilai subjek dalam penugasan. Subjek menjadi semangat menerapkan kemandirian belajar karena mendapatkan pujian dari orang tua dan guru serta sesekali mendapatkan hadiah dari orang tuanya. Adapun orang tua juga konsisten meneruskan pendampingan belajar dengan menerapkan aspek-aspek filial terapi, pendampingan dengan sikap yang positif memberikan keuntungan bagi mereka untuk membantu anak menjadi lebih giat terlibat dalam aktivitas belajar, mandiri untuk menulis, meningkatkan ketertiban dan pencapaian akademik berupa nilai yang sekamin membaik.

\section{Hasil dan Pembahasan}

\section{Hasil}

Setelah melakukan serangkaian intervensi berupa konseling dan Filial terapi dengan target memberikan pemahaman dan 4 keterampilan pada orang tua yaitu: a) Keterampilan imajiner yang berpusat pada anak; b) Keterampilan penataan; c) Keterampilan empatik; d) Keterampilan menetapkan batas, selanjutnya terapis menugaskan kepada orang tua untuk menerapkan secara konsisten keempat keterampilan tersebut dalam mendampingi subjek ketika bermain dan belajar sehari-hari. Dalam melakukan pendampingan belajar orang tua ditugaskan untuk menerapkan aspek filial terapi dan dikolaborasikan dengan teknik modifikasi perilaku berupa token ekonomi. Dimana melalui kombinasi pendampingan dan pemberian konsekuensi positif dengan teknik token ekonomi, akan diukur efeknya pada peningkatan kemandirian belajar pada subjek. 
Token ekonomi yang diterapkan pada subjek dilakukan dengan memberikan stampel senyum setelah ia menerapkan minimal 1 perilaku kemandirian belajar pada setiap aspeknya: (1) Aspek Motivasi terdiri dari 2 perilaku konkrit yaitu kemauan ketika diajak belajar dan sebagian besar tulisan di selesaikan sendiri; (2) Aspek Emosional, terdiri dari 2 perilaku konkrit yaitu tidak terpengaruh untuk bermain pada saat belajar selama durasi minimal 10 menit dan tidak menangis ketika menemukan kesulitan dalam mengerjakan; (3) Aspek Kognitif terdiri dari 2 perilaku konkrit yaitu dapat menuangkan isi pikiran untuk mengerjakan tugas dengan jawaban yang benar dan berinisiatif menjawab secara verbal dengan jawaban yang tepat ketika diuji dengan pertanyaan; dan (4) Aspek Prososial yang terdiri dari 3 perilaku konkrit yaitu mau belajar bersama orang lain, saling membantu dalam belajar, tidak mengganggu teman yang lain dalam belajar.

Jumlah stampel yang minimal harus dikumpulkan dalam sehari agar dapat ditukarkan dengan hadiah dari orang tua adalah 4 stampel senyum. Dengan syarat setiap aspek minimal mendapatkan 1 stampel.

Adapun rangkuman jumlah stampel senyum yang dikumpulkan oleh anak setiap harinya pada setiap aspek kemandirian belajar dirangkum dalam tabel dan untuk mempermudah keterbacaan dipaparkan dalam Tabel 1 dan Gambar 1 .

Selain itu pada orang tua juga diberikan lembar self report untuk melaporkan konsistensi pendampingan belajar dengan penerapan aspek-aspek filal terapi kedalam bentuk sikap-sikap yang mendorong kemandirian anak mengerjakan tugasnya sendiri. Adapun perilaku yang dilaporkan penerapannya terdiri dari 3 bentuk perilaku positif yaitu: (1) Memberi kesempatan kepada anak untuk mengerjakan sendiri, (2) Menyemangati, (3) Mengapresiasi keberhasilan dengan memuji, memberikan sentuhan fisik seperti memeluk dan mengelus kepala

Gambar 2 merupakan kurva yang merangkum hasil penerapan perilaku positif yang dilakukan orang tua dalam mendampingi subjek pada aktivitas belajar:

Berdasarkan penerapan tersebut diperoleh gambaran bahwa setelah mendapatkan pendampingan belajar dengan sikap yang lebih empatik dari orang tua dan pemberian reward melalui teknik token ekonomi anak menunjukkan peningkatan kemandirian belajar.

Adapun karena mendapat konsekuensi yang menyenangkan dari penguatan sosial berupa pujian, motivasi, afeksi yang positif dari orang tua serta konsekuensi menyenangkan dari penerapan token ekonomi berupa stampel senyum yang dapat ia kumpulkan dan selanjutnya ditukarkan dengan hadiah, maka beberapa perilaku sudah ditunjukkan oleh subjek secara konsisten seperti: 1) bersedia untuk diajak menyiapkan dan menyimpun kembali alat tulisnya sendiri mau menulis sendiri tugas-tugas yang diberikan di kelas, 2) tidak menangis ketika menemukan kesulitan dalam mengerjakan tugas, mau belajar bersama teman yang lain, 3) dapat menuangkan isi pikiran untuk menjawab soal dengan benar baik secara tertulis maupun verbal (walaupun dalam penerapannya subjek masih kerapkali mendapatkan bantuan berupa contoh

Tabel 1. Penerapan aspek kemandirian belajar

\begin{tabular}{lccc}
\hline Aspek & $\begin{array}{c}\text { perilaku } \\
\text { Target }\end{array}$ & $\begin{array}{l}\text { Pra } \\
\text { Intervensi }\end{array}$ & $\begin{array}{l}\text { Pasca } \\
\text { Intervensi }\end{array}$ \\
\hline Motivasi & 2 & 0 & 2 \\
Emosional & 2 & 0 & 2 \\
Kognitif & 2 & 1 & 2 \\
Prososial & 3 & 0 & 2 \\
\hline Total & 9 & 1 & 8 \\
\hline
\end{tabular}




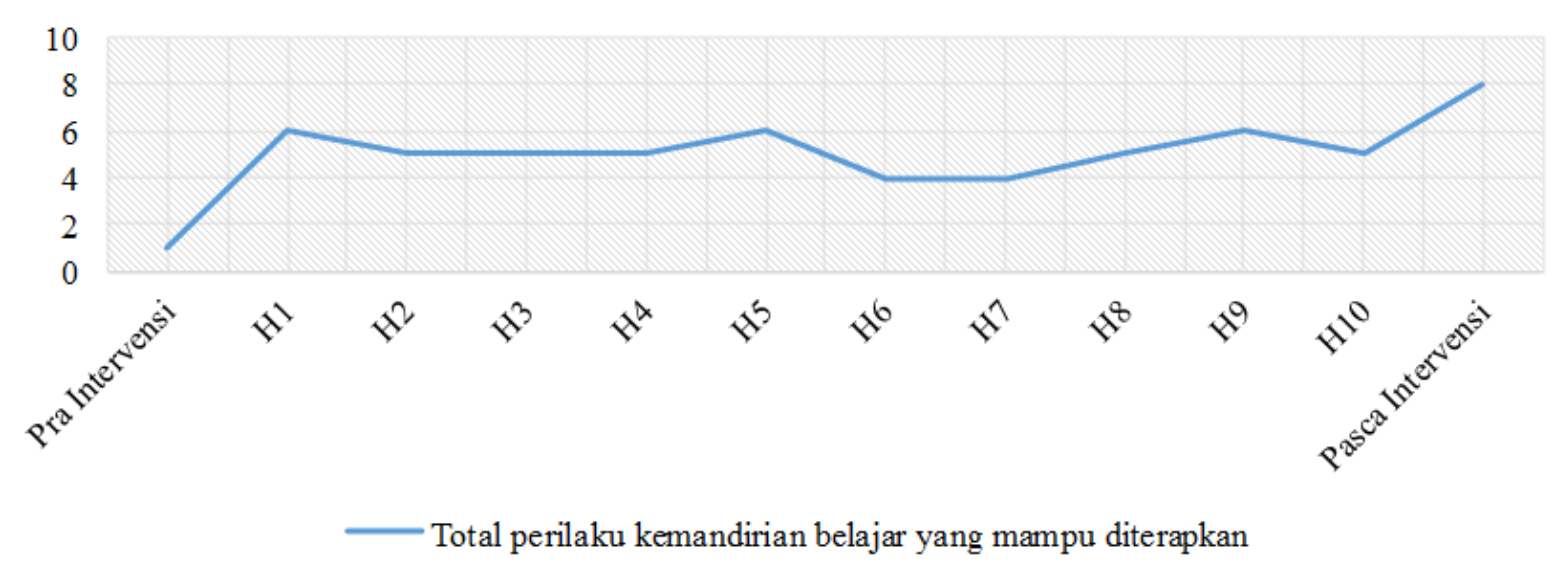

Gambar 1. Diagram Penerapan Perilaku Kemandirian Belajar.

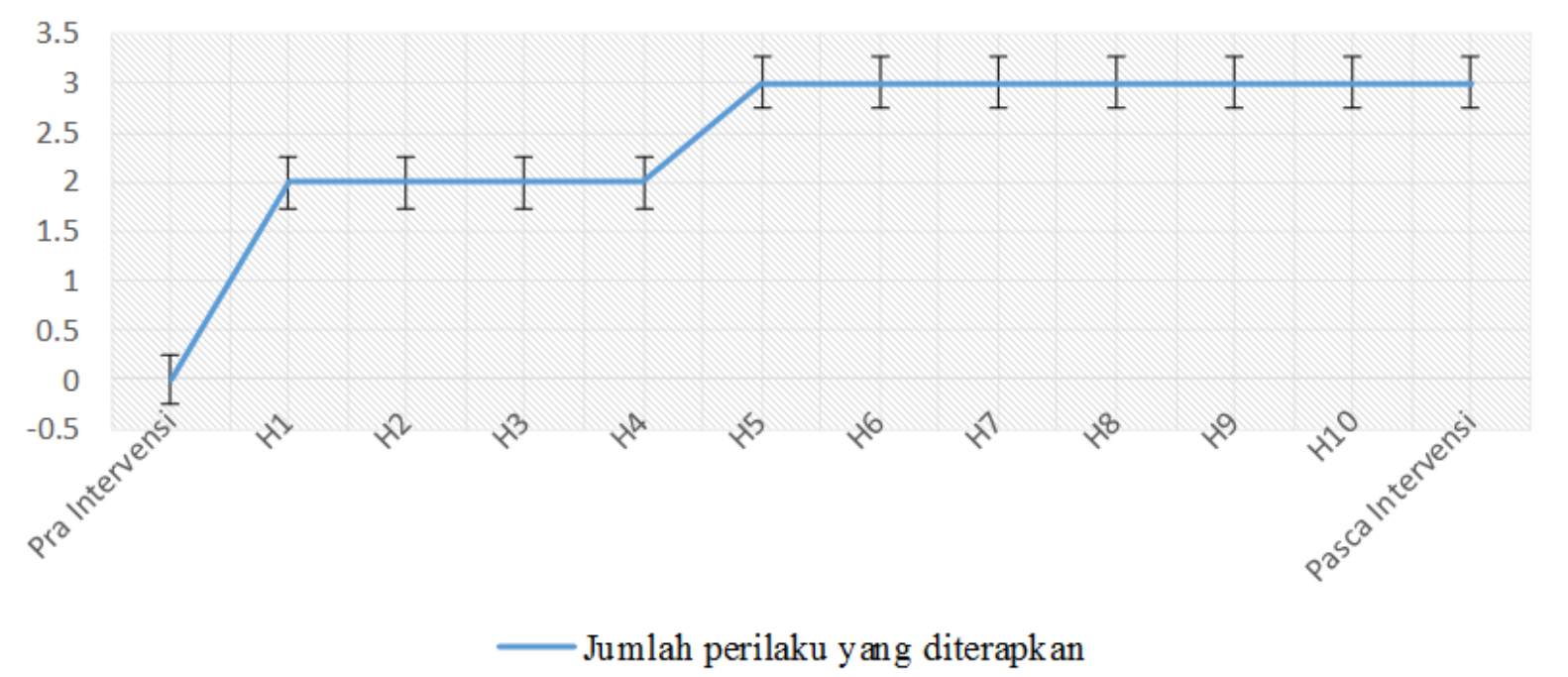

Gambar 2. Jumlah sikap positif pasca intervensi.

dari guru maupun orang tua ketika berkaitan dengan menulis jawaban, dikarenakan ia belum begitu lanjar dalam membaca dan belum menghafal seluruh huruf).

Disisi lain, beberapa perilaku subjek yang masih tidak sesuai dengan target adalah, terkadang pada mata pelajaran yang dilakukan siang hari masih terpengaruh untuk bermain di jam pelajaran, belum terampil untuk membantu temannya dalam mengerjakan tugas karena keterbatasan subjek yang belum lancar membaca. Selain itu dalam penerapan token ekonomi orang tua juga melaporkan bahwa mereka sempat tidak konsisten pada peraturan token ekonomi yang dilakukan dengan beberapakali tetap memberikan konsekuensi hadiah ketika subjek merengek menangis kepada subjek padahal subjek tidak memebuhi target menulis yang disepakati. Hal ini menjadi kekurangan dalam penanganan ini sekaligus koreksi untuk penerapan kelanjutan pendampingan belajar bagi orang tua agar membiasakan konsisten menerapkan peraturan token ekonomi yang sudah mereka pelajari ketika ingin mewujudkan target-target perilaku adaptif lainnya.

Berdasarkan hasil penerapan pendampingan belajar dengan menerapkan keterampilan filial pada orang tua dan kolaboratif dengan token ekonomi, secara umum orang tua telah mampu melakukan pendampingan belajar dengan sikap yang positif kepada anak serta membangun kepercayaan kepada anak untuk menyelesaikan penugasan sekolah secara mandiri. Adapun Subjek menunjukkan perubahan kemandirian belajar kearah yang lebih baik yang ditunjukkan 
dengan konsisten untuk menulis di rumah maupun di sekolah serta lebih banyak terlibat dalam menyelesaikan tugas-tugas sekolah dengan mengarahkan kemampuan kognitifnya sendiri.

\section{Pembahasan}

Berdasarkan hasil dari penerapan aspek pada filial terapi dalam mendampingi anak belajar secara empatik mampu memberikan pengaruh terhadap kemunculan perilaku-perilaku yang menunjukkan ciri-ciri kemandirian belajar seperti ketertarikan ketika diajak untuk mengerjakan tugas dan belajar, dilanjutkan dengan menulis dan mengerahkan kemampuan untuk menyelesaikan tugas sendiri, mempertahankan fokus untuk tidak bermain pada proses belajar selama durasi belajar yang disepakati, tidak mengganggu orang lain pada waktu belajar, mau belajar bersama dan membantu teman untuk pelajaran atau tugas-tugas yang ia kuasai, tidak menngis ketika menemukan penugasan yang sulit, mampu memberikan jawaban dengan tepat secara verbal ketika diuji pertanyaan dalam bentuk lisan.

Sebagin besar dari perilaku tersebut sudah mampu diterapkan oleh subjek dalam aktivitas belajarnya, adapun kemauan untuk menulis yang terbentuk dengan baik menjadi faktor utama yang menjadikan subjek terlibat lebih intens pada berbagai aktivitas belajar dimana secara tidak langsung membat subjek menjadi lebih patuh terhadap peraturan yang berlaku selama proses belajar dilakukan di sekolah maupun di rumah.

Subjek menjadi antusias dalam menulis karena dalam proses belajar ia mulai mendapatkan pengalaman pendampingan yang menyenangkan dan empatik dari orang tua, yang diterapkan dengan: selalu ada kesepakatan waktu antara belajar dan jeda bermain, subjek boleh memilih pelajaran apa yang ingin ia pelajari bersama orang tua, subjek diberi kesempatan untuk mencoba menjawab terlebih dahulu, menggunakan media belajar yang menyenangkan seperti kartu huruf, pensil warna dan gambar-gambar pola huruf yang membantunya dalam belajar menulis, dan mengeja, serta penguatan positif yang bersifat emosional diberikan dalam bentuk pujian, senyuman, sentuhan fisik seperti mengelus kepala ataupun memeluk.

Kemandirian belajar anak dapat dibangun melalui serangkaian praktik yang kompleks dan sangat terampil di mana semua jenis dukungan instrumental diberikan untuk memungkinkan anak-anak mengembangkan keterampilan belajar mandiri. Penelitian menunjukkan bahwa penggunaan cara kerja kooperatif, bersama dengan gaya evaluatif yang tidak mengancam dan berorientasi pada penguasaan, adalah dua elemen penting mendukung terbangunnya kemandirian belajar pada anak. Disisi lain, memberi anak-anak peran yang lebih besar dalam pengambilan keputusan di kelas, sehingga memberi mereka tanggung jawab dan kepemilikan atas pembelajaran mereka sendiri (David et al, 2005)

Orang tua subjek melaporkan bahwa mereka sebisa mungkin mulai meminimalisir kebiasaan menggunakan kekerasan fisik saat mendampingi subjek, sehingga subjek tilak lagi sulit untuk diajak belajar. Hal tersebut dikarenakan belajar berangsur-angsur menjadi aktivitas yang menyenangkan bagi subjek dan membuat ia mau untuk mencoba mengerjakan tugas sekolahnya sendiri tanpa mengkhawatirkan bentakan ataupun kekerasan fisik yang sebelumnya sering ia alami seperti dicubit, dijewer dan dipukul ketika ia menjawab dengan keliru.

Sejalan dengan teori bahwa FT secara efektif ditunjukkan efektif sebagai tindakan pencegahan seperti memperkuat hubungan antara orang tua dengan anak, memberikan pemahaman kepada orang tua terkait keterampilan pengasuhan sesuai dengan perkembangan anak (VanFleet, 2005).

Berbagai hasil penelitian menunjukkan bahwa FT meningkatkan keterampilan pengasuhan yang positif dan sehat (Bratton, Landreth \& Blackard, 2006). Selain itu penelitian lain juga menemukan bahwa FT memiliki kontribusi pada penurunan stres orang tua, dan peningkatan efektivitas pengasuhan dan hubungan orang tua-anak Foley et al. (2006). Hal tersebut dikarenakan orang tua belajar keterampilan menyampaikan penerimaan, empati, dan dorongan 
kepada anak mereka, dan untuk fokus pada peningkatan hubungan anak dan dengan anak daripada masalah anak perilaku (Perry et al, 2002) FT terbukti lebih sukses dan efektif daripada metode terapi bermain lain karena orang tua terlibat dalam proses terapeutik (Vigrass, 2006)

Selain itu kolaborasi penerapan token ekonomi juga menjadi faktor yang turut mempengaruhi dalam keberhasilan penerapan kemandirian belajar pada subjek. Walaupun tidak semua perilaku yang direncanakan dapat ia munculkan dengan konsisten, akan tetapi subjek mampu menunjukkan penerapan minimal 1 perilaku dalam setiap aspek kemandirian belajar. Pada aspek motivasi subjek secara konsisten memunculkan perilaku seperti mau ketika diajak belajar, menyiapkan dan menyimpun alat tulisnya sendiri, mau menulis sendiri sebagian besar tugasnya baik dikelas maupun di rumah. Pada aspek emosional, subjek secara konsisten memunculkan perilaku tidak menangis ketika menemukan kesulitan dalam mengerjakan. Pada aspek kognitif subjek secara konsisten menunjukkan perilaku berinisiatif menjawab secara verbal dengan jawaban yang tepat ketika diuji dengan pertanyaan secara lisan. Sedangkan pada aspek prososial subjek secra konsisten memunculkan perilaku yaitu mau belajar bersama orang lain. Konsekuensi menyenangkan berupa hadiah yang ia dapatkan setelah mampu mengumpulkan stampel dalam jumlah tertentu membuat subjek termotivasi untuk menerapkan sebagian besar target perilaku yang disepakati, dimana keseluruhan perilaku tersebut adalah pembiasaan agar subjek mau terlibat secara mandiri untuk mengerjakan tugas sekolahnya sendiri.

Dari Hasil penelitian tersebut terbukti bahwa token economy (penghargaan yang diberikan secara berulang) akan mengubah perilaku yang diharapkan menjadi kebiasaan baik. Reward juga dapat meningkatkan kepuasaan dan kesenangan. Hal ini juga dapat dikaitkan dengan salah satu pendapat ahli bahwa dengan teknik token economy, siswa dapat memperlihatkan perilaku yang diinginkan (kemandirian belajar) pada proses pembelajaran di kelas menerima reward berupa stampel senyum, kemudian reward tersebut dapat peserta didik tukarkan dengan hadiah yang lebih bermakna atau mengandung nilai pendidikan (Azreena \& Hanafi, 2018). Hasil penelitian ini sejalan hasil intervensi pada subjek dimana penggunaan token economy sebagai reward dapat memotivasi subje sebagai siswa untuk lebih antusias dalam ikut berpartisipasi dalam proses pembelajaran berlangsung, kususnya dalam intervensi adalah berperilaku mandiri saat belajar.

\section{Simpulan}

Filial terapi yang dikolaborasikan dengan Token Ekonomi berperan dalam meningkatkan kemandirian belajar pada subjek yang spesifik pada perilaku menulis dan mengerjakan tugas sekolah secara mandiri di sekolah maupun di rumah. Selain itu, penerapan target secara realistis serta pemilihan aktivitas yang menyesuaikan dengan kapasitas intelektual serta kemampuan subjek juga menjadi prinsip yang membantu tercapainya target intervensi.

Melalui proses pemahaman pada orang tua untuk memperbaiki sikap dan cara stimulasi dalam pendampingan belajar dapat membantu mengubah suasana belajar menjadi lebih empatik bagi subjek. Selain itu token ekonomi berperan untuk mempercepat perubahan dan tercapainya target karena melalui konsekuensi menyenangkan berupa hadiah subjek menjadi semangat untuk terlibat memunculkan perilaku mandiri dalam belajar belajar. Kemandirian belajar selanjutnya berkontribusi pada peningkatan nilai akademis subjek di sekolah

\section{Referensi}

Alivandi, M., dan Ismaila, K. (2010). Parents as agents of change: what filial therapy has to offer. Procedia Social and Behavioral Sciences 5 2165-2173doi:10.1016/j.sbspro.2010.07.431

Azreena, N., and Hanfi, N.Token Economy to Improve Concentration among Students with Learning Disabilities in Primary School. Journal of ICSAR 2,(1)

Bavin-Hoffman, R., Jennings, G., \& Landreth, G. (1996). Filial therapy: Parental perceptions of the process. International Journal of Play Therapy, 5(1), 45-58. 
Bratton, S., Landreth, G. L., Kellam, T., \& Blackard, S. R. (2006). Child Parent Relationship Therapy (CPRT) treatment manual: A 10-session filial therapy model for training parents. New York, NY: Routledge

Bryan, T., \& Sullivan-Burstein, K. (1997). Homework how-to's. Teaching Exceptional Children, 29(6), 32-37.

Bugental, D., Johnston C.,New, M., Silvester, J. (1998). Measuring Parental Attributions: Conceptual and Methodological Issues. Journal of Family Psychology, 12(4), 459-480

David et al. (2005). Developing Independent Learning In The Early Years. International Journal of Primary, Elementary and Early Years Education, 33(1)

Doll C, McLaughlin TF, Barretto A. 2013. The token economy in recent review and evaluation. International Journal of Basic and Applied Science, 2(1):131-149. Foley, Y. C., Higdon, L., \& White, J. F. (2006). A qualitative study of filial therapy: Parents' voices. International Journal of Play Therapy, 15(1), 37-64. doi: $10.1037 / \mathrm{h} 0088907$

Guerney, L. (2003). The history, principles, and empirical basis of filial therapy. In R. VanFleet \& L. Guerney (Eds.), Casebook of filial therapy (pp. 1-20).

Perry, N.E., VandeKamp, K.J.O., Mercer, L.K. \& Nordby, C.J. (2002) Investigating Teacher-Student Interactions That Foster Self-Regulated Learning. Educational Psychologist, 37, 1, 5-15

Syover, L., Guerney, B.G. 1967. The efficacy of training procedures for mothers in filial therapy.1967. Psychotherapy: Theory, Research And Practice Volume 4,

VanFleet, R., Topham, G. (2011). Filial Therapy: A Structured and Straightforward Approach to Including Young Children in Family Therapy. The Australian And New Zealand Journal Of Family Therapy Volume 32 Number 2, 144-158

Vigrass, Andrea. 2006. Connecting parents and children through filial therapy: eight filial therapy group lesson plans. A Project Submitted to the School of Graduate Studies of the University of Lethbridge in Partial Fulfillment of the Requirements for the Degree: University of Lethbridge

Williams, J. (2003) Promoting Independent Learning in the Primary Classroom. Buckingham: Open University Press. 